\title{
Antibacterial activity of medicinal plants used in Ayurvedic medicine towards food and water borne pathogens
}

ISSN: 0254-8704 (Print)

Authors Info

I. M. Nair', V. Anju ${ }^{2}$ and A. A. M. Hatha ${ }^{3 *}$

'School of Environmental Sciences, Mahatma Gandhi University, P.D. Hills, Kottayam-686 560, India

${ }^{2}$ Department of Botany, Kuriakose Elias College, Mannanam, Kottayam-686 560, India

${ }^{3}$ Department of Marine Biology, Microbiology and Biochemistry, School of Marine Sciences, Cochin University of Science and Technology, Cochin-682 016, India

*Corresponding Author Email : mohamedhatha@gmail.com

Key words

Antibacterial activity, Aqueous extracts, Ayurvedic medicine Medicinal plants,

Pathogenic bacteria

Publication Info

Paper received : 17.07.2015

Revised received : 07.06.2016

Re-revised received : 30.06 .2016

Accepted: 30.07 .2016
Abstract

Aim : In the emerging scenario of increasing multiple antibiotic resistance among pathogenic bacteria, plant based extracts having antibacterial activity are being explored as a means to check the emergence of drug resistant mutants. In the present study, aqueous extracts from various parts of twenty four different plants used in Ayurvedic medicine were evaluated for their antibacterial activity against water and food borne pathogens such as Salmonella, Escherichia coli, Vibrio, Aeromonas, Bacillus and Staphylococcus.

Methodology : Antibacterial activity of plant extracts from various parts of twenty four different plants was evaluated by agar well method. Antibiotic sensitivity testing was carried out by Kirby-Bauer method. The diameter of inhibition zones was measured in millimetres. Inhibition zone with diameter less than $12 \mathrm{~mm}$ were considered as having no antibacterial activity. Diameters between 12 and $16 \mathrm{~mm}$ were considered as moderately active, and greater than $16 \mathrm{~mm}$ were considered as highly active.

Results : Out of 33 extracts prepared from various officinal parts, 23 extracts showed antibacterial activity ranging from narrow spectrum to broad spectrum. Tamarindus indica, Garcinia gummi-gutta and Allium sativum possessed excellent broad spectrum antibacterial activity. While inhibitory activity against Salmonella was widespread among many plants, some of the plant extracts showed specific activity towards Staphylococcus aureus. Interpretation : The study revealed that the Gram positive bacteria were more susceptible to crude plant extracts than Gram negative ones. Some of the plant extracts showed superior antibacterial activity when compared to antibiotics. Antibacterial properties of plants analysed might be helpful in discovery of new plant based bactericidal compounds to control drug resistant bacteria.
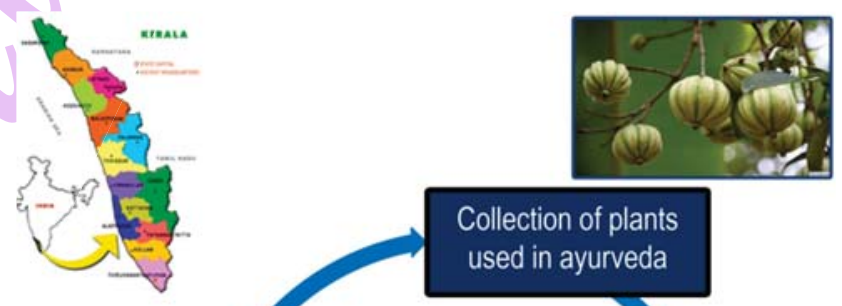

Collection of plants used in ayurveda
Selection of study area

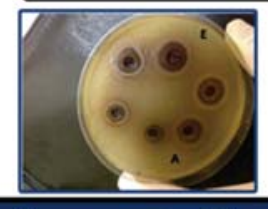

Measurement of the diameter of zone of inhibition aqueous extracts

Antibacterial sensitivity testing against pathogenic bacteria
Preparation of 


\section{Introduction}

Ayurveda known as the 'science of life' is a system of traditional medicine native to the Indian subcontinent and a form of alternative medicine which is more than 5000 years old. Nature has been a source of medicinal agents for thousands of years, and an impressive number of modern drugs have been isolated from natural sources, many based on their use in traditional medicine. The core concept lies on the mutual relationship of man and nature. Plants have provided a source of insight for developing novel drug compounds, as they were used traditionally for the welfare of human beings (Maurice et al., 1999). Indigenous plants have served as a major source of drugs for centuries and have been used by our ancestors (Hong-Fang et al., 2009).Though the accepted modern medicine has gradually evolved by the scientific and observational hard work of many scientists, the basis of its development remains rooted in traditional medicine and therapies (Bhushan et al., 2004). Most of the drugs available in the market today have been derived from the natural products.

Repeated and improper use of antibiotics in the treatment of human as well as animal production system has resulted in the assortment of drug resistant mutants. Drug resistance among bacteria is of concern among health practioners as the infection caused by them are difficult to treat. This resistance in bacteria is a serious threat in healthcare now a days and can arise in a significant minority of infected patients and mostly for the one who have other basic health conditions, regular medications and repeated exposure to antibiotics (Hooper et al., 2012). While the innovation of new antibiotics is not keeping rapidity with the emergence of drug resistant mutants, different options are being sought to reduce the selection pressure for drug resistant mutants in the environment. While cautious use of antibiotics is a vital step, other step is screening of plant based alternatives i.e., secondary metabolites that have bactericidal activity. In this view, the antibacterial activity of some medicinal plants used in Ayurvedic medicinal practices were evaluated against some food and water borne pathogenic bacteria.

\section{Materials and Methods}

Selection of plant materials and preparation of aqueous extracts : Twenty four plant species belonging to 20 different families were selected for evaluating the antibacterial properties. Based on the therapeutic uses of different parts of the plant, in some cases more than one part of the same plant viz. roots, stem, leaves, flowers and fruits were used. Details of the plant analysed is presented in Table 1. Fresh plants were collected randomly from local areas and were identified with the help of herbarium maintained in the School of Environmental Sciences, Mahatma Gandhi University, Kerala, India.

The plant parts were cleaned and washed in sterile distilled water. In order to obtain plant extracts, about $100 \mathrm{~g}$ of each washed plant parts were crushed with mortar and pestle by

Table 1 : List of plants and the officinal parts evaluated

\begin{tabular}{|c|c|c|c|}
\hline Botanical name & Vernacular name (Malayalam) & Family & Officinal parts used \\
\hline Nerium oleanderL. & Arali & Apocynaceae & Leaf \\
\hline Clerodendrum infortunatum L. & Thettaparamaram & & Leaf \\
\hline Chromolaena odorata (L.) King and Robinson & Communist Pacha & Asteraceae & Leaf and stem \\
\hline Abelmoschus esculentus L.Moench. & Venda & Malvaceae & Fruit \\
\hline Morus albaL. & Mulberry & Moraceae & Leaf \\
\hline Ficus religiosa L. & Arrayal & Moraceae & Leaf \\
\hline Averrhoa bilimbiL. & Irumpanpuli & Oxalidaceae & Leaf and fruit \\
\hline Cassia fistula L. & Kanikkonna & Fabaceae & Leaf \\
\hline Tamarindus indica L. & Valanpuli & Fabaceae & Leaf and fruits \\
\hline Ocimum americanum L. & Kattuthulasi & Lamiaceae & Leaf \\
\hline Leucas aspera (Willd.) link & Thumba & Lamiaceae & Leaf, stem,flowers \\
\hline Curcumalonga L. & Manjal & Zingiberaceae & Rhizome \\
\hline Zingiber officinale Roscoe & Inchi & Zingiberaceae & Rhizome \\
\hline Calotropis gigantea L. & Erukku & Asclepiadaceae & Leaf and flower \\
\hline Garcinia gummi-gutta (L.) Roxb. & Kudampuli & Clusiaceae & Leaf and fruits \\
\hline Piperbetle L. & Vettila & Piperaceae & Leaf \\
\hline Moringa oleifera Lam. & Muringa & Moringaceae & Leaf and fruit \\
\hline Psidium guajava L. & Pera & Myrtaceae & Leaf and fruit \\
\hline Aloe vera L. Burm.F & Kattarvazha & Xanthorrhoeaceae & Leaf \\
\hline Murraya koenigii L. & Kariveppu & Rutaceae & Leaf \\
\hline Azadirachta indicaA. Juss. & Aryaveppu & Meliaceae & Leaf \\
\hline Scoparia dulcis L. & Kallurukki & Scrophulariaceae & Leaf \\
\hline Coriandrum sativum L. & Malli & Apiaceae & Leaf \\
\hline Allium sativum L. & Velluthulli & Lilliaceae & Bulb \\
\hline
\end{tabular}


adding sterile distilled water. The extracts were sieved through a fine mesh cloth. After centrifugation at $1500 \mathrm{rpm}$ for 20 minutes, the supernatants were sterilized using a membrane filter (0.45micron sterile filter). These crude extracts were transferred into sterile test tubes.

Bacterial strains : Pathogenic bacteria belonging to both Gram positive and Gram negative bacterial strains were used in the present study to evaluate the broad spectrum activity of the medicinal plants. The Gram positive strains used in the present study were Staphylococcus aureus and Bacillus subtilis, while Gram negative strains includes eight strains of Salmonella, two strains of Vibrio, three strains of Escherichia coli and Aeromonas hydrophila. A. hydrophila, Stapylococcus aureus and B. subtilis cultures were obtained from the culture collection of Institute of Microbial Technology (IMTECH), Chandigarh, India. Among Salmonella, the strains S. paratyphi, S. mgulani, S. bareily, S. enteritidis, S. senftenberg, S. typhi, S. bovis, S. weltevreden and S. worthington were included in the present study. While $S$. paratyphi, S. mgulani, S. typhi, S. weltevreden and $S$. senftenberg were isolated from seafood, $S$. worthington, $S$. bareily and $S$. enteritidis were isolated from chicken. The serotypes of E.coli include 025, 086 and O63. The strains of Vibrio selected in the present study were V. cholerae and V. vulnificus. E. coli and Vibrio strains were isolated from the Cochin estuary in a previous investigation funded by Department of Science and Technology, Govt. of India.

Antibacterial sensitivity testing using agar well method (Cup Plate Method) : Using a sterile cotton swab, the bacterial cultures enriched in sterile nutrient broth for $6-8 \mathrm{hrs}$ at $37^{\circ} \mathrm{C}$ were swabbed on the surface of sterile Mueller-Hinton Agar (MHA) plates. Agar wells were prepared with the help of sterilized cork borer with $10 \mathrm{~mm}$ diameter. Using a micropipette, $100 \mu \mathrm{l}$ of plant extracts were added to different wells in the plate. The plates were incubated in an upright position at $37^{\circ} \mathrm{C}$ for $24 \mathrm{hrs}$. The diameter of inhibition zones was measured in millimetres. Inhibition zone with diameter less than $12 \mathrm{~mm}$ were considered as having no antibacterial activity. Diameters between 12 and $16 \mathrm{~mm}$ were considered as moderately active, and greater than $16 \mathrm{~mm}$ were considered as highly active (Bauer et al.,1966).

Antibiotic sensitivity testing (Kirby-Bauer Method) : The test bacterial pathogens were also tested for their sensitivity against antibiotics such as Pencillin, Ampicillin, Chloramphenicol, Ciprofloxacin, Kanamycin, Erythromycin, Lincomycin, Gentamycin, Vancomycin, Amikacin, Nitrofurantoin, Novobiocin, Nalidixic acid, Streptomycin and Tetracycline by the disk diffusion method. The antibiotic discs were aseptically placed over the seeded MHA plates and were incubated at $37^{\circ} \mathrm{C}$ for $24 \mathrm{hrs}$. The diameter of the inhibition zones were measured in millimetres and were compared with the standard Kirby-Bauer chart to group them into resistant and sensitive. Based on this interpretation chart (Bauer et al., 1966), the inhibition zone size were categorised as susceptible (S), intermediate (I) or resistant (R).

\section{Results and Discussion}

In the present study, crude extracts of 24 plants, which were used in Indian medicinal practices, were tested against both Gram negative and Gram positive strains. On the basis of the medicinal aspects of different parts of the plants, 33 extracts were prepared. Fourteen extracts showed excellent antibacterial activity (zone of diameter greater than $16 \mathrm{~mm}$ ) and nine extracts showed moderate activity. Ten extracts possessed no antibacterial activity which includes stem of $C$. odorata, leaf of $N$. oleander, A. vera, F. religiosa, C. gigantea, C. fistula, S. dulcis, flower of $C$. gigantea, stem of $L$. aspera and rhizome of $Z$. officinale. The results are given in Table 2.

Leaf extracts of Clerodendrum infortunatum, Averrhoa bilimbi, Moringa oleifera, Murayya koenigii, Azadirachta indica and Chromolaena ordata showed good to moderate antibacterial activity against Salmonella strains, with diameter of inhibition zone ranging up to $24 \mathrm{~mm}$, depending on the type of plant. Maximum activity against Salmonella was shown by curry leave (M. koenigii) extract. Curry leaves are an indispensable ingredient in many of the Indian dishes. While we found the activity of the above leaf extracts were specific to Gram negative forms, Modi et al. (2010) reported antibacterial activity of ethanolic extracts of the leaves of $C$. infortunatum against $E$. coli, B. subtilis and S. aureus. Stanley et al. (2014) also reported moderate bactericidal activity of solvent based leaf extracts of $C$. odorata. Contradictory to our observations some of the researchers (Ifeanyichukwu et al., 2015) reported broad spectrum activity of the above leaf extracts. Notable among is the widespread antibacterial activity of neem extract against $A$. hydrophila and V. cholera (Raut et al., 2014), S. aureus (Mistry et al., 2014) and B. subtilis (Raut et al., 2014).

Fruit extracts of $A$. bilimbi, Tamarindus indica and Garcinia gummigutta showed excellent broad spectrum antibacterial activity. These fruit extracts were able control the growth of both gram negative and gram positive bacteria. The fruit extract of $A$. bilimbi controlled the growth of all test pathogens analysed in this study, except $A$. hydrophila, $V$. vunificus and $E$. coli, while that of $T$. indica showed excellent activity against all the strains except $S$. aureus and $E$. coli 086 . The zone of inhibition caused by fruit extract of $\mathrm{T}$. indica against $\mathrm{S}$. senftenberg was 36 $\mathrm{mm}$. Whole fruits of A. bilimbi and T. indica and the pods of $G$. gummigutta are widely used in the preparation of many south Indian dishes. A. bilimbi fruits are also used to make pickles. Antibacterial activity of these fruits besides their culinary value makes them an attractive ingredient to various dishes. Another plant which showed remarkable broad spectrum antibacterial activity was $G$. gummigutta. In case of $T$. indica and $G$. gummigutta leaf extracts also showed good broad spectrum 
Table 2 : Diameters of inhibition zones of plant extracts against different pathogenic bacterial strains by agar well method

\begin{tabular}{|c|c|c|c|c|c|c|c|c|c|c|c|c|c|c|c|c|c|c|}
\hline \multirow[t]{2}{*}{ Plants } & \multicolumn{18}{|c|}{$\begin{array}{l}\text { Diameter of inhibition zone (millimeters) } \\
\text { Bacterial strains used }\end{array}$} \\
\hline & $\begin{array}{l}\text { Parts } \\
\text { used }\end{array}$ & & $S M$ & SBa & $S E$ & SS & $S B$ & ST & SWe & SW & $A H$ & $V C$ & $W$ & $\begin{array}{l}E C \\
O 25\end{array}$ & $\begin{array}{l}E C \\
086\end{array}$ & $\begin{array}{l}E C \\
063\end{array}$ & $\begin{array}{l}B S \\
G^{+v e}\end{array}$ & $\begin{array}{l}S A \\
G^{+v e}\end{array}$ \\
\hline Nerium oleander & $\mathrm{L}$ & 0 & 0 & 0 & 0 & 0 & 0 & 0 & 0 & 0 & 0 & 0 & 0 & 0 & 0 & 0 & 0 & 0 \\
\hline Clerodendrum infortunatum & $\mathrm{L}$ & 12 & 18 & 12 & 20 & 20 & 0 & 17 & 12 & 16 & 12 & 0 & 0 & 0 & 0 & 0 & 0 & 0 \\
\hline Chromolaena odorata & $\mathrm{L}$ & 15 & 15 & 15 & 0 & 0 & 14 & 0 & 12 & 13 & 0 & 0 & 0 & 0 & 0 & 0 & 0 & 0 \\
\hline Chromolaena odorata & $S$ & 0 & 0 & 0 & 0 & 0 & 0 & 0 & 0 & 0 & 0 & 0 & 0 & 0 & 0 & 0 & 0 & 0 \\
\hline Abelmoschus esculentus & $\mathrm{Fr}$ & 0 & 0 & 0 & 0 & 0 & 0 & 0 & 0 & 0 & 17 & 0 & 0 & 15 & 0 & 0 & 0 & 0 \\
\hline Morus alba & $L$ & 0 & 0 & 15 & 12 & 15 & 0 & 14 & 12 & 12 & 0 & 0 & 0 & 0 & 0 & 0 & 0 & 0 \\
\hline Ficus religiosa & $\mathrm{L}$ & 0 & 0 & 0 & 0 & 0 & 0 & 0 & 0 & 0 & 0 & 0 & 0 & 0 & 0 & 0 & 0 & 0 \\
\hline Averrhoa bilimbi & $\mathrm{L}$ & 0 & 0 & 0 & 21 & 13 & 0 & 0 & 0 & 12 & 0 & 0 & 0 & 0 & 0 & 0 & 0 & 0 \\
\hline Averrhoa bilimbi & $\mathrm{Fr}$ & 12 & 12 & 18 & 16 & 15 & 16 & 14 & 15 & 16 & 0 & 15 & 0 & 0 & 0 & 0 & 0 & 17 \\
\hline Cassia fistula & $L$ & 0 & 0 & 0 & 0 & 0 & 0 & 0 & 0 & 0 & 0 & 0 & 0 & 0 & 0 & 0 & 0 & 0 \\
\hline Tamarindus indica & $\mathrm{L}$ & 15 & 14 & 16 & 16 & 0 & 18 & 15 & 15 & 14 & 14 & 15 & 16 & 0 & 16 & 17 & 0 & 16 \\
\hline Tamarindus indica & $\mathrm{Fr}$ & 24 & 22 & 20 & 20 & 22 & 36 & 22 & 22 & 22 & 17 & 18 & 16 & 14 & 15 & 0 & 17 & 0 \\
\hline Ocimum americanum & $\mathrm{L}$ & 0 & 0 & 0 & 0 & 0 & 0 & 0 & 0 & 0 & 13 & 0 & 0 & 0 & 0 & 0 & 15 & 0 \\
\hline Leucas aspera & $\mathrm{L}$ & 0 & 14 & 0 & 0 & 0 & 12 & 0 & 0 & 11 & 0 & 0 & 0 & 0 & 0 & 0 & 0 & 0 \\
\hline Leucas aspera & $S$ & 0 & 0 & 0 & 0 & 0 & 0 & 0 & 0 & 0 & 0 & 0 & 0 & 0 & 0 & 0 & 0 & 0 \\
\hline Leucas aspera & $\mathrm{FI}$ & 0 & 0 & 0 & 0 & 0 & 0 & 0 & 0 & 0 & 0 & 12 & 0 & 0 & 0 & 0 & 13 & 0 \\
\hline Curcuma longa & $\mathrm{Rh}$ & 0 & 15 & 0 & 14 & 15 & 0 & 14 & 0 & 14 & 12 & 0 & 0 & 0 & 0 & 0 & 14 & 14 \\
\hline Zingiber officinale & $\mathrm{Rh}$ & 0 & 0 & 0 & 0 & 0 & 0 & 0 & 0 & 0 & 0 & 0 & 0 & 0 & 0 & 0 & 0 & 0 \\
\hline Calotropis gigantea & $\mathrm{L}$ & 0 & 0 & 0 & 0 & 0 & 0 & 0 & 0 & 0 & 0 & 0 & 0 & 0 & 0 & 0 & 0 & 0 \\
\hline Calotropis gigantea & $\mathrm{Fl}$ & 0 & 0 & 0 & 0 & 0 & 0 & 0 & 0 & 0 & 0 & 0 & 0 & 0 & 0 & 0 & 0 & 0 \\
\hline Garcinia gummi-gutta & $\mathrm{L}$ & 12 & 12 & 13 & 12 & 12 & 16 & 17 & 12 & 12 & 0 & 15 & 0 & 0 & 13 & 0 & 12 & 12 \\
\hline Garcinia gummi-gutta & $\mathrm{Fr}$ & 19 & 21 & 19 & 0 & 19 & 24 & 21 & 21 & 17 & 20 & 26 & 19 & 16 & 20 & 17 & 22 & 20 \\
\hline Piper betle & $\mathrm{L}$ & 0 & 0 & 12 & 12 & 12 & 16 & 0 & 12 & 14 & 0 & 0 & 0 & 0 & 0 & 0 & 0 & 0 \\
\hline Moringa oleifera & $\mathrm{L}$ & 16 & 0 & 15 & 16 & 13 & 14 & 12 & 15 & 14 & 0 & 16 & 0 & 0 & 0 & 0 & 0 & 25 \\
\hline Moringa oleifera & $\mathrm{Fr}$ & 0 & 0 & 15 & 20 & 19 & 17 & 14 & 0 & 15 & 0 & 0 & 0 & 0 & 0 & 0 & 0 & 22 \\
\hline Psidium guajava & $\mathrm{L}$ & 0 & 0 & 0 & 0 & 0 & 0 & 0 & 0 & 0 & 0 & 0 & 0 & 0 & 0 & 0 & 0 & 15 \\
\hline Psidium guajava & $\mathrm{Fr}$ & 0 & 0 & 0 & 0 & 0 & 0 & 0 & 0 & 0 & 0 & 0 & 0 & 0 & 15 & 0 & 0 & 23 \\
\hline Aloe vera & $\mathrm{L}$ & 0 & 0 & 0 & 0 & 0 & 0 & 0 & 0 & 0 & 0 & 0 & 0 & 0 & 0 & 0 & 0 & 0 \\
\hline Murraya koenigii & $\mathrm{L}$ & 0 & 12 & 12 & 24 & 12 & 0 & 12 & 16 & 12 & 0 & 0 & 0 & 0 & 0 & 0 & 0 & 0 \\
\hline Azadirachta indica & $\mathrm{L}$ & 12 & 12 & 14 & 12 & 12 & 12 & 12 & 13 & 12 & 0 & 0 & 0 & 0 & 0 & 0 & 0 & 0 \\
\hline Scoparia dulcis & $\mathrm{L}$ & 0 & 0 & 0 & 0 & 0 & 0 & 0 & 0 & 0 & 0 & 0 & 0 & 0 & 0 & 0 & 0 & 0 \\
\hline Coriandrum sativum & $\mathrm{L}$ & 0 & 0 & 0 & 0 & 0 & 0 & 0 & 0 & 0 & 24 & 0 & 0 & 0 & 0 & 0 & 0 & 0 \\
\hline Allium sativum & Bulb & 27 & 28 & 31 & 30 & 27 & 26 & 27 & 29 & 29 & 28 & 20 & 17 & 29 & 22 & 26 & 38 & 28 \\
\hline
\end{tabular}

SP: Salmonella paratyphi, SM: Salmonella mgulani, SBa: Salmonella bareily, SE: Salmonella enteritidis, SS: Salmonella senftenberg, SB: Salmonella bovis, ST: Salmonella typhi, SWe: Salmonella weltevreden, SW: Salmonella worthington, AH: Aeromonas hydrophila, VC: Vibrio cholerae, VV: Vibrio

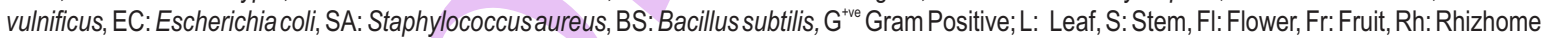

antibacterial activity. Fruit extract of G. gummigutta was able to inhibit the growth of all pathogenic strains analysed in this study except $S$. enteritidis. Antibacterial activity of $A$. bilimbi (Nwaivu et al., 2012), T. indica (Trila et al., 2014; Routhu et al., 2015) and G. gummigutta (Semwal, 2015) has been reported previously, though with minor variations in activity against different pathogens. This variation could be due to the strain variations among the pathogens or due to variations in the plant species according to geographical locations. Antimicrobial activity of $T$. indica is attributed to the presence of phenolic acids and flavanoids (Trila et al., 2014).
Moderate antibacterial activity has been observed in the leaf extracts of Leucas aspera, Piper betle and Ocimum americanum. While the leaf extract of $O$. americanum showed good activity against $A$. hydrophila and $B$. subtilis, $L$. aspera leaf extracts were effective in inhibiting S. mgulani, S. bovis and $B$. subtilis. Flower extracts of $L$. aspera could control growth of $V$. cholera and $B$. subtilis. This variation in the activity of different parts of the plant is interesting and needs further studies to identify the phytochemical responsible for the antibacterial activity. Our observation about the antibacterial activity of flower extracts of $L$. aspera is in tune with the findings of Chew et al (2012). 
Table 3: Classification based on the antibacterial activity, based on inhibition zone diameter in millimetres

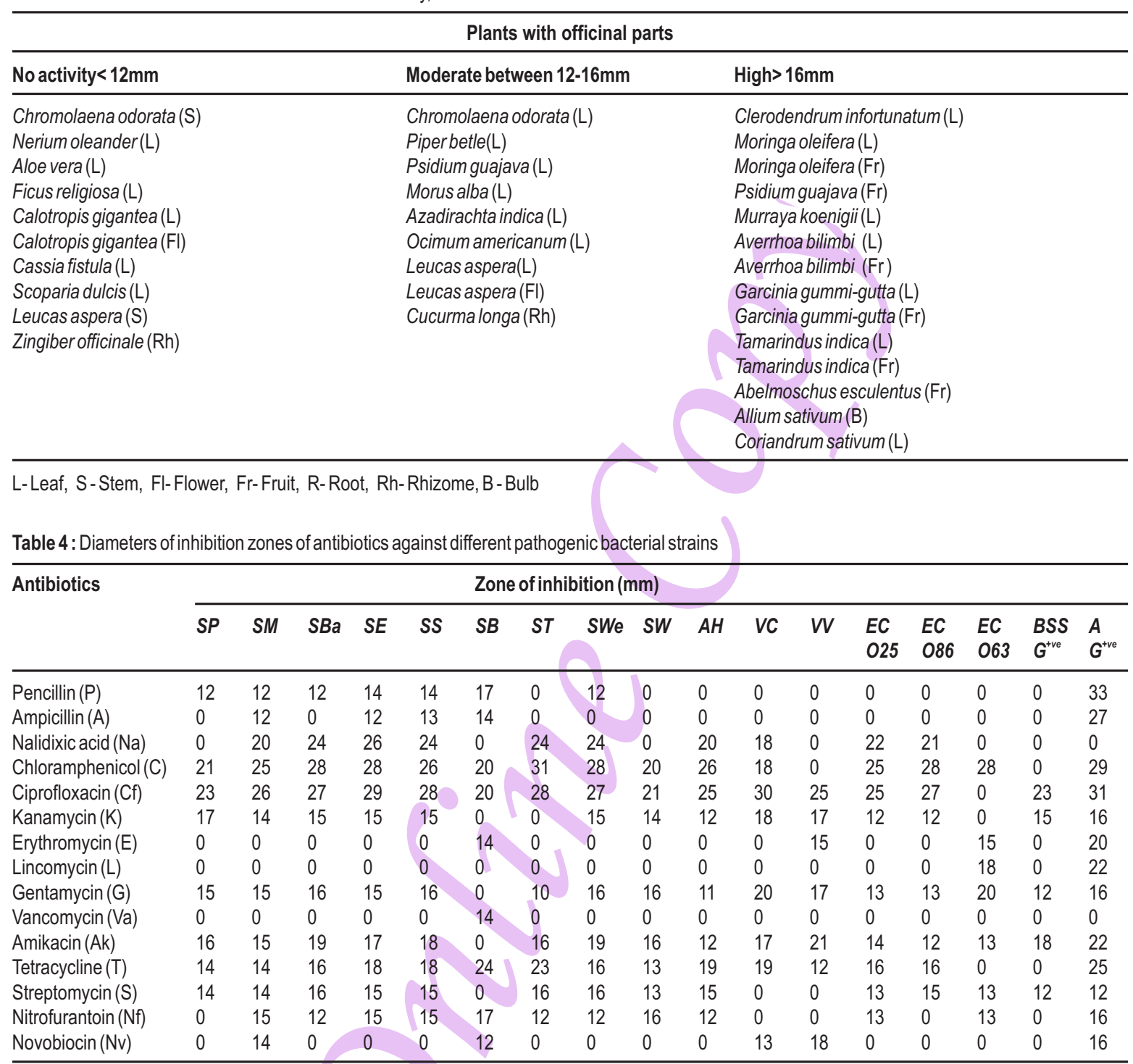

SP: Salmonella paratyphi, SM: Salmonella mgulani, SBa: Salmonella bareily, SE: Salmonella enteritidis, SS: Salmonella senftenberg, SB: Salmonella bovis, ST: Salmonella typhimurium, SWe: Salmonella weltevreden, SW: Salmonella worthington, AH: Aeromonas hydrophila, VC: Vibrio cholerae, VV: Vibrio vulnificus, EC: Escherichia coli, SA: Staphylococcus aureus, BS: Bacillus subtilis, G $\mathrm{G}^{\text {te }}$ : Gram Positive

Antibacterial activity of $P$. betle leaf extract was limited to various serotypes of Salmonella. All the Gram positive bacterial strains as well as those belonging to Gram negative strains such as $A$. hydrophila, Vibrio and $E$. coli were not inhibited by the leaf extract of this plant. However, solvent based extracts of $P$. betle are reported to inhibit $E$. coli, S. aureus and V. cholera. P. betle leaves are widely used by Indian public for chewing along with tobacco.

Another plant which showed specific antibacterial activity against Gram positive pathogen S. aureus was M. oleifera, which corroborate the findings of Peixoto et al. (2011). The leaf and fruit extracts of this plant inhibited the growth of $\mathrm{S}$. aureus with zone of inhibition ranging from 25 and $22 \mathrm{~mm}$ respectively. However, these extracts failed to inhibit the growth of other Gram positive pathogen $B$. subtilis analysed in this study. The fruit extract of this plant exhibited moderate activity against Salmonella serotypes, except S. paratyphi and S. mgulani. Growth of $E$. coli was not inhibited by the leaf or fruit extracts of $M$. oleifera, which corroborates the findings of previous researchers (Piexoto et al., 2011; Trondel et al., 2014). Growth of S. aureus was also inhibited 
by the leaf and fruit extracts of Psidium guajava, the guava plant. While leaf extract was specific in its action against $S$. aureus (diameter of inhibition zone $15 \mathrm{~mm}$ ), fruit extract showed broad range antibacterial activity and inhibited the growth of $S$. bovis, $E$. coli and $S$. aureus, with diameter of inhibition zone ranging from 22 to $23 \mathrm{~mm}$.

Gram negative pathogen A. hydrophila was inhibited by the leaf extract of Coriandrum sativum, which is widely used spice in Indian cookery. Similarly the extracts from the bulb of garlic Allium sativum showed very good broad spectrum antibacterial activity against the various test pathogens evaluated in the present study. Maximum zone of inhibition of this extract was recorded against $B$. subtilis ( $38 \mathrm{~mm}$ ) and minimum was against $V$. vulnificus (17 mm). Indu et al. (2006) reported the potential of bulb extract of $A$. sativum in controlling the growth of both gram positive and negative bacterial strains. Antibacterial activity of $C$. sativum is attributed to the presence of essential oils in this leaves.

Based on the diameter of inhibition zones obtained from the agar well method, the activity of plant extracts were classified as no or least $(<12 \mathrm{~mm})$, moderate $(12-16 \mathrm{~mm})$ and high ( $>16$ $\mathrm{mm})$. The results are represented in the Table 3 . Out of the 33 aqueous extracts prepared from the officinal parts of 24 plants, 10 extracts showed least activity against the test organisms. Fourteen plants were found to have excellent antibacterial property and nine with moderate activity.

The plant extracts which control the growth of both Gram positive and negative strains were categorised to have broad spectrum activity and those which control any one were categorised as narrow spectrum. Of the 23 plant extracts with bactericidal activity, 12 possess and 11 with narrow spectrum activity. Results revealed that Gram positive pathogens included in this study are more susceptible to the crude plant extracts tested when compared to Gram negative ones. Similar observations were reported previously (Janakiraman et al., 2012). Both these groups of researchers also reported that Gramnegative bacteria were more resistant to the action of antibacterial compounds than Gram-positive strains. This is attributed to the presence of hydrophilic outer membrane rich in lipopolysacchride molecules and enzymes associated with periplasmic space which is capable of breaking down the foreign molecules (Shan et al., 2007) In case of Gram-positive bacteria such outer membranes and cell wall structures were lacking (Chowdhury et al., 2004).

Generally it was observed from this study that strains of Salmonella were highly susceptible to the action of plant extracts. Strains of $E$. coliwere resistant to the bactericidal properties of the extracts of plant officinal parts. The resistance is in the order $E$. coli $>$ Vibrio $>B$. subtilis $>A$. hydrophila $>S$. aureus $>$ Salmonella. When the activity of officinal parts of the plants was compared, the bulb extract were found to have excellent activity in inhibiting the growth of both Gram positive and negative strains. The potential of the plant's officinal parts is in the sequence of Bulb > Fruit > Flower $>$ Rhizome $>$ Leaf.

The pathogenic strains were also tested against 15 standard antibiotics that were commonly used for treating microbial infections (Table 4) for an authentication with the antibacterial activity of plant extracts. Antibiotics namely nalidixic acid, chloramphenicol and ciprofloxacin showed excellent activity. The zone of inhibition observed from the fruit extract of Tamarindus indica and Garcinia gummi-gutta, bulb extract of Allium sativa clearly implicit their potency to control the growth of pathogenic strains, compared to above tested antibiotics. The diameter of the inhibition zone obtained against garlic extract was comparable to those obtained against chloramphenicol and ciprofloxacin. The other antibiotics namely tetracycline, amickacin, novobiocin, nitrofurantoin, streptomycin, gentamycin, vancomycin, erythromycin, kanamycin and lincomycin showed only moderate antibacterial activity against the test pathogens. The extracts of plants give promising results when compared to the activity of antibiotics.

The use of different plant based natural compounds as antibacterial agents is an interesting strategy to combat emerging multidrug resistant (MDR) pathogens. The increasing consumer demand for effective, safe, natural products, calls for the research interest in the study of phytochemicals. Ingenious screening programs are required to discover the plant based antimicrobials with diverse chemical structures and mechanisms of action. Screening strategies adopted in this study provides good route to select particular plants, that in the near future could provide useful therapeutic tools in controlling the antibiotic resistant bacteria.

\section{Acknowledgment}

The authors would like to express their thanks to Jawaharlal Nehru Memorial Fund and Department of Environment and Climate Change, Kerala State for their support in this research.

\section{References}

Akter, K.N., P. Karmakar, A. Das, S.N. Anonna, S.A. Shoma and M.M. Sattar: Evaluation of antibacterial and anthelmintic activities with total phenolic contents of Piper betel leaves: Avicenna J. Phytomed., 4, 320-329 (2014).

Bauer, A.W., W.M.M. Kirby, J.C.T. Sherris and M. Turck: Antibiotic susceptibility testing by a standardized single disk method. Am. J. Clin. Pathol., 45, $493-496$ (1966).

Bhushan, P., A.D.B. Vaidya and C. Mukund: Ayurveda and natural products drug discovery. Curr. Sci., 86, 6-25 (2004).

Chew, A.L., J.J.A. Jessica and S. Sasidharan: Antioxidant and antibacterial activity of different parts of Leucas aspera: Asian Pac. J. Trop. Biomed., 2, 176-180 (2012).

Chowdhury, A.A. and M.S. Islam: Antibacterial activity of Trema orientalis. Dhaka University J. Pharam. Sci., 3, 115-117 (2004). 
Dash, B.K., S. Sultana and N. Sultana:Antibacterial activities of methanol and acetone extracts of fenugreek (Trigonella foenum) and coriander (Coriandrum sativum). Life Sci. Med. Res., 2011, 1-8 (2011).

Hong-Fang, J., L. Xue-Juan and Z. Hong-Yu: Natural products and drug discovery: Can thousands of years of ancient medical knowledge lead us to new and powerful drug combinations in the fight against cancer and dementia? EMBO reports, 10, 194-200 (2009).

Hooper, D.C., A.J. McAdam, A. DeMaria, B.M. Limbago, T.F. O'Brien and B. McCaughey: Antibiotic resistance: How serious is the problem, and what can be done? Clini. Chem., 58, 1182-1186 (2012).

Ifeanyichukwu, I., E. Chika, N. Emmanuel, O. Anthonia, A. Ngozi and N. Agabus: Preliminary investigation of the antibacterial activity of Psidium guajava extracts. European J. Medi. Plants, 7, 26-30 (2015).

Indu, M.N., A.A.M. Hatha, C. Abirosh, U. Harsha and G. Vivekanandan: Antimicrobial activity of some of the south-Indian spices against strains of Escherichia coli, Salmonella, Listeria monocytogenes and Aeromonas hydrophila. Braz. J. Microbiol., 37, 153-158 (2006).

Janakiraman, N., S.S. Sahaya and M. Johnson: Antibacterial studies on Peristrophe bicalyculata (Retz.) Nees. Asian Pac. J. Trop. Biomed., 2, 147-150 (2012).

Karon, B., M. Ibrahim, A. Mahmood, A.K.M.M. Huq, M.M.U. Chowdhury, M.A.H. Hossain and M.A. Rashid: Preliminary antimicrobial, cytotoxic and chemical investigations of Averrhoa bilimbi Linn. and Zizyphus mauritiana Lam. Bangladesh Pharm. J., 14, 127131(2011).

Maurice, M.I., R.D. Angela and O.C. Okunji: New antimicrobials of plant origin. Perspectives on new crops and new uses: (Ed.:J. Janick ), ASHS Press, Alexandria (1999).

Mistry, K.S., Z. Sanghvi, G. Parmar and S. Shah: The antimicrobial activity of Azadirachta indica, Mimusops elengi, Tinospora cardifolia, Ocimum sanctum and $2 \%$ chlorhexidine gluconate on common endodontic pathogens: An in vitro study: Eur. J. Dent., 8, 172-177 (2014).

Modi, A.J., S.S. Khadabadi, I.A. Farooqui and D.S. Ghorpade: Studies on antimicrobial activity of Clerodendrum infortunatum, Argyreia nervosa and Vitex negundo: A comparison. Der. Pharmacia. Lettre., 2, 102-105 (2010).

Nwaiwu, N.E., F. Mshelia and I.A. Raufu: Antimicrobial activities of crude extracts of Moringa oleifera, Hibiscus sabdariffa and Hibiscus esculentus seeds against some enterobacteria. J. Appl. Phytotechnol. Environ. Sanit., 1, 11-16 (2012).
Oluduro, A.O.: Evaluation of antimicrobial properties and nutritional potentials of Moringa oleifera Lam. leaf in South-Western Nigeria. Malays. J. Microbiol., 8, 59-67 (2012).

Panchal, P., H. Bajaj and S. Maheshwari: Azadirachta indica (NEEM): antibacterial effects against Escherichia coli and Salmonella. Guru Drone J. Pharm. Res., 1, 18-21 (2013).

Peixoto, J.R.O., G.C. Silva, R.A. Costa, G.H.F. Vieira, A.A. Fonteles Filho and R.H.S. dos Fernandes Vieira: In vitro antibacterial effect of aqueous and ethanolic Moringa leaf extracts. Asian Pac. J. Trop. Biomed., 4, 201-204 (2011).

Prajapati, M.S., J.B. Patel, K. Modi and M.B. Shah: Leucas aspera: A review. Pharmacogn. Rev., 4, 85-87 (2010).

Prasad, M.P., S. Sushant and B.K. Chikkaswamy: Phytochemical analysis, antioxidant potential, antibacterial activity and molecular characterization of Clerodendrum species. Int. J. Mol. Biol., 3, 7176 (2012).

Raut, R.R., A.R. Sawant and B.J. Bhagyashree: Antimicrobial activity of Azadirachta indica (Neem) against pathogenic microorganisms. J. Acad. Ind. Res., 3, 327-329 (2014).

Routhu, N., B.V. Rao, G. Ramakrishna and N. Nagaraju: Antioxidant and antimicrobial activity of Tamarindus indica L leaves. Int. J. Adv. Res. Sci. Technol., 4, 333-338 (2015).

Semwal, R.B., D.K. Semwal, I. Vermaak and A. Viljoen: A comprehensive scientific overview of Garcinia cambogia. Fitoterapia, 102, 134148 (2015).

Shan, B., Y. Z. Cai, J.D. Brooks and H. Corke: The in vitro antibacterial activity of dietary spice and medicinal herb extracts. Int. J. Food Microbiol., 117, 112-119 (2007).

Shirazi, M.T., H. Gholami, G. Kavoosi, V. Rowshan and A. Tafsiry: Chemical composition, antioxidant, antimicrobial and cytotoxic activities of Tagetes minuta and Ocimum basilicum essential oils. Food Sci. Nutr., 2, 146-155 (2014).

Stanley, M., O. Ifeanyi and O. Eziokwu: Antimicrobial effects of Aloe vera on some human pathogens. Int. J. Curr. Microb. App. Sci., 3, 10221028 (2014).

Torondel, B., D. Opare, B. Brandberg, E. Cobb and S. Cairncross: Efficacy of Moringa oleifera leaf powder as a hand-washing product: A crossover controlled study among healthy volunteers. BMC Comple. Alter. Med., 14, 14-57 (2014).

Trila, U.F.J, P.A.J. Lopezb, Alvarezb and V.M. Martosb: Chemical, physico-chemical, technological, antibacterial and antioxidant properties of rich-fibre powder extract obtained from tamarind (Tamarindus indica L.). Ind. Crops Prod., 55, 55-162 (2014). 